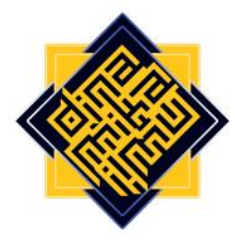

\title{
An Integrated Quality Education Management in the Perspective of the Qur'an Qs. As- Syu'ara' Verses 181-183 in Tafsir Al-Misbah
}

\author{
Sa'dullah Assa'idi \\ Graduate Program, Islamic University of Nahdlatul Ulama (UNISNU) Jepara, \\ Central Java, Indonesia \\ Email: sadullah@unisnu.ac.id \\ Azizil Muchtar \\ Graduate Program, Islamic University of Nahdlatul Ulama (UNISNU) Jepara, \\ Central Java, Indonesia \\ Email: azizil.muhtar@gmail.com \\ Mashudi \\ Graduate Program, Islamic University of Nahdlatul Ulama (UNISNU) Jepara, \\ Central Java, Indonesia \\ Email:mashudi_69@yahoo.co.id
}

Abstract

This research was aimed at revealing and understanding the principle of customer satisfaction of the integrated quality education management in the Qur'an OS AsSyu'ara' Verses 181-183, and the implication of the integrated quality education management. This study used content analysis where a qualitative approach was employed. Integrated quality management on education was analyzed its component by consulting the messages and guides in the Qur'an OS As-Syuara' Verses 181-183 interpreted in the Tafseer Almisbach authorized by Indonesian Islamic scholar Prof. Dr. Quraish Shihab. Results show that quality management in education roots in Islamic teaching that to practice a continued improvement in the entire life. The quality appears as daily worship that should improve day by day. Al Misbach provides guidance and enlightens that education management is a complete measure. Accordingly, you don't become one of the members of the groups of people who hurts oneself because of harming others but weigh for yourself and others using an accurate scale, don't hurt others concerning their 
Sa'dullah Assa'idi et.al.

rights by reducing the quality or the value of something, and don't make the evil on earth by becoming destroyers in any form after the repair is made by Allah or also by human beings. If you give something to humans, thus perfect the scale, and don't you reduce the weight by giving them less than it should be.

Keywords: Customer satisfaction management, education quality, Tafsir Al-Misbach

\section{A. Introduction}

The Qur'an as a Muslim holy book functions among others as "human" full of various guides to make humans able to become good caliphs on earth. To get the guidance, it needs a study of the Qur'an itself, so that the Muslims may take maximum benefits from the contents of the Qur'an, wherein, complex problems that have occurred, are occurring, and will occur are discussed. All matters that are related to human life, either the existence of this nature have been stated in The Qur'an, including the matters from the origin of humans to activities the people do such as Education Management, all of which have been written in the Qur'an (Hidayat \& Wijaya, 2017).

It is known that the main sources of Islamic education are the Qur'an and hadiths, and also the opinions of the companions and the ulema or Muslim scientists as the addition. Islamic education as a discipline should open the eyes that the condition of education at present is far from what we expect. We hope that Islamic education contributes to education in Indonesia, but it has not maximumly been realized yet. One of the factors is that a principle as a basis for education is not applied (Muhammad \& Sulistyorini, 2012; Bunza \& Abdulkarim, 2021).

Education is the main factor in shaping the character of humans. It is a universal activity in human life. Anywhere in the world where people live, education may be found (Taufikin, 2021). Although education is a general symptom in each community life, it is the differences in the philosophy and the views of life adopted by each nation or community that cause the distinctions in the implementation including the differences in the education system (Fathurrohman \& Sulistyorini, 2012).

The nature of management is al-adbir (regulation). The success of the educational process is also dependent upon the educational institution's management pattern. Although at present Islamic educational institutions have begun developing their education quality, especially in their management, but it should be recognized that the efforts are still in the form of imitation by patching work here and there or in other words, by adopting the models developed by general educational institutions. It means that there is a feeling of self-worth that what may be done by general educational institutions may also be conducted by Islamic educational institutions (Ramayulis, 2008: Rosdiarini, 2020).

At the moment, the development of the thought of managing an educational institution leads to a management system called TOM (Total Quality Management) or 
Integrated Quality Management (IOM). Principally, this management system is comprehensive surveillance from all members of the organization to educational activities (Hermanto, 2018). The application of TOM means that all educational institutions are responsible for the quality of education. Before it is reached, all parties involved in the academic process should understand the nature and the goal of education (Rukiyah, Kadir \& Ulfah, 2021). In other words, each individual involved should understand the purpose of providing education. In other words, each individual involved should understand the purpose of providing education. Without such a comprehensive understanding, it is impossible to apply the TOM (Sallis, 2014).

In the TQM, educational institutions should position the students as "clients" or in the company management term as the greatest "stakeholders". Therefore, the students' voices should be taken into account in each strategic decision made in education. Without a democratic atmosphere, the management will not be able to apply the TOM, and what will happen is that the quality of education is dominated by certain parties that often own interest deviating from the nature of education (Crawford \& Shutler, 1999).

Quality now is an important issue discussed in almost every sector of life, among businessmen, the government, the educational system, and other sectors. Quality is all characteristics of a product or a service to fulfill the customers' needs and expectations. Customers in the world of education are the students, the student parents, the community, or the government. These customers require quality educational institutions namely educational institutions that may bear golden generations, namely the generations who have faith, knowledge, morals, and qualified competencies (Salih, 2008; Vincent, 2001). An education institution that is always in demand by the community is the one that is good in managing the existing resources, accountable, qualified and that can compete with other institutions and that may facilitate its students to study at a higher education level or to enter into the world of work with the stock of knowledge and technology and technical skills which are needed by the world of business and industry. It is these institutions that we name quality and good educational institutions (Saputro, 2015; Komariah \& Triatna, 2008).

Quality is not something that immediately happens and emerges before the teachers, staff, and the principal. Quality management is a systematic process to continuously improve the quality of the teaching-learning process and factors related to it. It is expected that this becomes the target of Islamic educational institutions and it may be reached effectively and efficiently. Quality should be managed by applying the quality trilogy: planning, supervision, and improvement that are continuously carried out in line with the development of the customers' needs. It is based on the size, content, provision, and evaluation of the quality of goods or services (product) in accordance with customer satisfaction (Vlašić et al., 1996).

IQM or known as TQM is indeed a process and a basic philosophy that may be successful if it is simultaneously applied at all levels of the organization. The application of the TQM does not require tools or a new management system, except a commitment or an awareness to make cultural changes that are oriented toward the increase of quality and 


\section{Sa'dullah Assa'idi et.al.}

the improvement of all processes continuously, comprehensively, and sustainably. The TQM certainly may be applied in any organization without exception. By giving attention to the ways of application, in what field the philosophy is adopted, and how to deal with obstacles hindering the application in tertiary education organizations, the implementation that takes a long time will run well (Koch \& Fisher, 1998).

Moreover, if the procedures are well conducted, success will be in our hands, either it is an individual or an organization. Quality-focused education is that the basis of the mission of quality is where a school develops programs and services that meet the users' needs namely students and the community. The community in question is wide as the graduate users, namely the business world, further educational institutions, the government, and the public, including establishing their own businesses. A TQM serves as a philosophy and a methodology to help manage changes, and the essence of the TOM is cultural changes made by the actors (Nurkolis, 2003; Caldwell, 2005).

TQM is a management strategy intended to implant a quality awareness in all processes of an organization In accordance with the definition given by the ISO, TOM is an approach to management for a quality-centered organization, on the basis of the participants of all members and with the aim of gaining a long term success through customer satisfaction and of giving benefits to all members of an organization or the community (Briggs \& Wohlstetter, 2003).

Based on the descriptions above, the objective of this present research is to understand integrated quality education management and to reveal theories or what IQM of Islamic Education is considered to be more relevant with the Qur'an.

Drawing quality management in mind, this study defines three research questions to be sought:

1) What are the general structure and ideas represented in the Tafseer of Almisbach to perceive OS Os. As- Syu'ara' Verses 181-183 in Tafsir Al-Misbah?

2) How is quality management in education perceived based on the Tafseer of Almisbach to perceive OS Qs. As- Syu'ara' Verses 181-183 in Tafsir Al-Misbah?

3) How an implication is made in the implementation of quality education management based on the Tafseer of Almisbach to perceive OS Qs. As- Syu'ara' Verses 181-183 in Tafsir Al-Misbah?

\section{B. Literature Review}

\section{The Definition of Customer Satisfaction}

Satisfaction is from the Latin language, satis meaning enough, so a product or a service that may be satisfactory is the product or the service that is able to give something being looked for by consumers at an adequate level. While a customer is someone or a group of people who accept the product or service. Gasperz defines a customer as someone who is not dependent on us, but it is us who depend on him. A customer is one who brings us to his desires. No one may win in making arguments with a customer. A customer is someone who is really important so that she/he cannot be erased. While Kotler said that customer satisfaction in this matter someone's glad or disappointed feelings. 
Nasution citing Tse and Wilton stated that customer satisfaction or dissatisfaction is a response given by a customer to the evaluation of discrepancy or discord felt between an expectation before (or another norm of performance) and the actual performance of a product after it is used. In summary, customer satisfaction is the level of one's feeling after comparing the performance or result he feels and that of one's expectations.

Yamit stated that customer satisfaction is an evaluation of the after purchase or the results of evaluation after comparing what is felt and what is expected in two dimensions. First is internal use or customer. It consists of teachers, librarians, laboratory assistants, technicians, and administrative staff. The second type of customer is the external one. External customers include primary customers namely students, and secondary ones namely the student parents, and tertiary ones is the graduate recipients. Customer satisfaction or dissatisfaction is a customer's response to the evaluation of discrepancy or discord felt between the previous expectation (and another norm of performance) and the actual performance of the product felt after it is used. In conclusion, customer or consumer satisfaction is the level of one's feeling after comparing the performance of the product he felt and his expectations. Customer satisfaction is the response given by a customer to the evaluation of incompatibility between previous expectations or the norm of other performance and the performance of the actual product felt after being used. It is an emotional response in the evaluation of the experiences in consuming a product or service.

In addition, the term quality is a subjective and relative terminology that may be interpreted in various ways where each definition may be supported by an equally good argument. Extensively, quality may be meant as characteristics of a product or service that may satisfy consumers/costumers' needs. The characteristic of quality may be measured quantitatively and qualitatively. in education, quality is a learning process that is pleasing and giving enjoyment and success. Customers (internal and external) may be those who directly become the receivers of the product or service or those who still feel the benefits of the product and service.

Education quality management may be interpreted as an art of science in managing services to satisfy the customers through quality assurance in order to avoid any complaints. For students, a school is a medium to study, and in its, there is a system consisting of input-process-output. As a result, a school plays an important role in realizing a learning atmosphere and a good learning process so that students may actively develop all of their potentials existing in themselves.

In the main principle of the focus on the customer in the integrated quality management theory, there are four main principles:

a. Quality is defined by customers not by the supplier for example a lesson should be in line with the goal.

b. A school should be closed with the customer so that it can fulfill his/her needs, for instance, the consulting briefing to the student parents should be adjusted with their time, instead of the teacher's time. 
Sa'dullah Assa'idi et.al.

c. A quality school knows its customers and takes opportunities to look for their needs and fondness, for example, the school may survey the parents or the students regarding aspects of school life.

d. Consumer satisfaction may be determined by the moment of truth that gives examples of good or bad quality. Quality is much included in the experiences of the customers than the service providers.

Therefore Islamic education should understand that each product of education has customers. Each member of Islamic education is a supplier and customer. There are two customers here, namely internal and external ones. Internal customers include student parents, students, teachers, administrators, staff, and school assembly. External customers are the community, heads of corporation-industry, government institutions, a private institutions, high education, and security agency. Islamic education will be regarded to have high quality and will attract the community if it can fulfill the customer expectations and satisfaction either internal or external ones.

\section{The Principle of Customer Satisfaction}

The principle of customer satisfaction of Islamic education, this principle emphasizes a consistent search for sustainable improvement to reach the need in integrated quality educational management. The strategy develops in using quality management in the world of education is that the educational institution should position itself as an institution of service or in other words an industry of service. The institution provides the service which is appropriate with it intended by a customer. A principle is a way of life believed by someone that may help himself to reach the intended or programmed purpose of life.

At present, attention to customer satisfaction or dissatisfaction is higher because principally the goal of a corporation or an educational institution is to create satisfaction for the customer. The higher the level of customer satisfaction, the corporation will get a higher profit because the customers will repurchase the product of the corporation. However, if the level of satisfaction felt by the customer is low, it might be that the customer will move to the product of the competitor.

Customer satisfaction included the differences between the expectations and the performance or the results felt. A customer is someone who receives the result of one's job or service (in this case is the output of the educational institution), so it is the customer that determines the quality of a product or an output), since the quality of a product is dependent on the level of the customer satisfaction in using the product. Concerning the Islamic Educational Institution, its quality relies on whether the community, that becomes the consumers of the educational institution, is satisfied with it or not.

Some important elements in the quality that are determined by the customers are: The customers should also become the main priority of the organization, the reliable customer is the most important one, namely a customer who buys repeatedly, and his satisfaction is guaranteed by making high-quality products with continuous improvement. Customer satisfaction in an educational institution may be seen from its active role in contributing the thought or fund without any coercion from the management of the 
educational institution.

Quality and customer satisfaction are related one and the other: quality gives a drive to a customer to make a strong relationship with the corporation. In the long term, this bond enables the corporation to understand the customer's expectations or his need carefully. Therefore, the corporation may improve customer satisfaction where the corporation maximizes its customer's pleasing experiences or minimizes or abolishes his less pleasant ones. Customer satisfaction in turn may create loyalty to the corporation that provides satisfactory quality.

To measure customer satisfaction, the customer often has four scenarios of different services in his mind about what he will possess namely: (1) Ideal services, (2) Expected/anticipated services, (3) Deservedly accepted services and (4) Tolerable minimum services. Customer satisfaction may be expected from the four scenarios. An expectation creates satisfaction if a minimum service that may be tolerated turns out to be the same or even exceeding the expectation. The factors that affect the expectation are the customer's needs, promises, and previous experiences. Customer satisfaction is very important, since whether he is satisfied or not greatly influences the advancement of a customer-oriented business.

There are five types of satisfaction and two types of dissatisfaction on the basis of the combination between specific emotions of the service provider, expectation regarding the capability of their performance of the future service provider, and the behavioral interest to re-select the service provider in question. First, demanding customer satisfaction indicates the relation with the service provides is colored with positive emotions, especially optimism and trust. The positive experiences in the past make a customer expects that the service provider will be able to meet his rising expectation in the future. Second, stable customer satisfaction is a customer who possesses passive aspiration and demanding attitudes. His positive emotion to the service provider is characterized by steadiness and trust in the relation maintained at present, where he or she expects something which is still the same. Third, resigned customer satisfaction indicates the satisfaction is not caused by the fulfillment of his/her expectation but is more based on an unrealistic impression. His/her behavior tends to be passive, and also to be unwilling to do efforts to demand improvement. Fourth, stable customer dissatisfaction is dissatisfied with the performance of the service provider but he tends to do nothing. The relation with the service provider is colored with negative emotions and the assumption of his/her expectations in the future will not be met, and there is no change for changes and improvement. Fifth, demanding customer dissatisfaction is characterized by the active aspiration and demanding attitude level. At the dissatisfaction emotion level, it may causes protests from the opposition to actively demand improvement. A dissatisfaction situation occurs after a customer uses the product or the service bought and he feels that the performance of the product does meet the expectation.

Quality management has the meanings of measurement, content, provision, and evaluation of the quality of a product or service that has absolute and relative characteristics. In the absolute sense, quality is a standard that is high and cannot be 


\section{Sa'dullah Assa'idi et.al.}

beaten. Usually, it is called good, superior, beautiful, expensive, luxurious, and so on. So if it is related to the context of education, the concept of the quality of education is elite, since there are few institutions that may give educational experiences with high quality to the students.

In the relative sense, quality has two definitions. The first is to adjust oneself to specifications. The second is to meet the needs for customer satisfaction. Quality in one's opinion is sometimes contradictory with the quality in other's view so that it is not strange if there are experts who do not have the same conclusion of how to create a good institution. Quality management is a science or an art that regulating the process of making use of human resources or other resources that support the attainment of a goal effectively and efficiently. Based on the size, content, provision, and evaluation of the quality of goods or services should be in line with customer satisfaction.

\section{Biography of the Author of Tafsir Al-Misbah}

M. Quraish Shihab was born in Pebruary 16, 1944 di Rappang, Sulawesi Selatan. He was one of the sons of Abdurrahman Shihab (1905-1986), a businessman, and a popular ulema. His father was a professor in the field of Exegesis, and once served as the rector of IAIAN Alauddin Makassar. He was also an initiator of the establishment of UMI (Universitas Muslim Indonesia, a leading private university in Makassar. Since childhood, Quraish Shibah has already been familiar with and has loved the Qur'an. At the age of 6-7 years old, he joined in a recitation of the Qur'an held by his own father.

At that time, besides asking to read the Quran, his father also described at glance stories in the Qur'an, read the news from the companions, and remarks from ancient scholars that mostly consisted of the majesty of the Qur'an and how to treat it well. This added his love and interest to study the Qur'an. Quraish Shihab to study the Qur'an. It is in this place, according to M. Quraish Shihab, that the seeds of his love for the Qur'an started growing. After completing his elementary school in Makassar, Quraish continued his study to Pondok Pesantren Dar al-Hadis/al-Faqihiyyah, located in Malang city, East Java. In the cool city, he studied in the pesantren for two years. In 1958, when he was 14 years old, he left to Cairo, Egypt. His desire to go to Cairo could be realized because of the scholarship assistance from the local government of Sulawesi.

In 1967, Quraish got the title of Lc (S1) from the faculty of Ushuluddin, department of Hadith Tafseer, al-Azhar University. In 1969, he succeeded in obtaining the title of MA with the specialization in the Tafseer of the Qur'an, where the title of his thesis is al-ljaz atTasyri' li al-Our 'an al-Karim. In 1980, he returned to Cairo and continued his education at his old alma mater, Al-Azhar University. In 1982, with his dissertation with the title of Nazm al-Durar li al-Biqa'i, Tahqiq wa Dirasah, he earned a doctorate degree in the Qur'an Science. For his achievement, he was listed as the first person from South East Asia to obtain the degree.

It is in 1984 that was a new stage in the second step for Quraish Shihab to continue his career. Therefore, he moved from IAIN Makassar to the Faculty of Ushuluddin in IAIN Jakarta and taught the Tafseer of the Quran and Ulum Qur'an in the S1, S2, and S3 until 
1998. Later, he was the Rector IAIN Jakarta (1992, 1996, and 1997-1998). After that, he was the Minister of Religion for less than two months, and at the beginning of 1998, he was appointed as the Ambassador Extraordinary and Plenipotentiary of the Republic of Indonesia for the state of Arab-Egypt and the Republic of Djibouti domiciled in Cairo. Besides teaching, he was the Chairman of the Central Indonesian Ulema Council (MUI), a member of Lajnah Pentashhih Al-Qur'an of the Department of Religion since 1989. He was also the Assistant to Chairman of the Indonesian Muslim Scholars (ICMI), the Committee of Sharia Sciences Association, and the Committee of Religious Sciences Consortium, Department of Education and Culture.

\section{Research Methodology}

The method adopted in this research was library research (Mellon, 2015; Zed, 2004). The primary data sources are books on tafseer or hadiths, the second data sources are works correlated with the discussion of education management, namely articles, books, or theses. The process carried out was to grouped verses or hadiths related to management and education, they were deeply traced to the tafseer of the verses of the Qur'an. The authors browsed the education management theories relevant to the research problems so that the relevance of the education management theories and the verses of the Qur'an and hadiths were sought (Mann, 2005).

In the data analysis, the authors employed a qualitative data analysis. To find the principle of customer satisfaction of the integrated quality education management in the Qur'an, the authors utilized a content analysis method. Content analysis is a technique to make replicable inferences and result in data validity by taking into account the context. As a research technique, this analysis included specific procedures to process scientific data with the aim of providing knowledge, opening new insights, and presenting data (Stemler, 2015).

Terminologically, a tafseer is a science in which it discusses God's words and what is intended with the content of human power. Another ta'rif explains that exegesis is to explain the meanings of verses and their existences, the stories, and the causes using clear sentences. While the Qur'an as the object of this article used Arabic that owns the complexity of meanings and which is formed in social contexts at present. Therefore, the data were analyzed using Tahlily and ljmali tafseer models (Al-Maraghi, 2012).

Tahlily method or Tajzi'iy method as Bafir Al-Shadr calls is a tafseer method where its mufassir tries to explain the contents of the verses of the Qur'an from various sides by taking into account the sequence of the verses of the Qur'an as stated in its mushhaf. In this case, the muffasir begins from one verse to the next, or from a surah to the next surah by citing the sequence of the verse or surahs in line with what is stated in the mushhaf. All aspects considered to be important by a tajzi'iy/tahlily is ordered, from the vocabulary, asbab al nuzul, munasahat, and others related to the text or the contents of the verse. After all the steps are taken, the tahlily muffasir then explains all aspects of all exegeses and the explanations above and then he gives a final explanation of the content and the meaning of the verse of the Qur'an (Yasin, 2020). 
Sa'dullah Assa'idi et.al.

ljmali method or it is also called a global method is the way of interpreting the verses of the Qur'an by showing the contents of meanings in a verse globally. In practice, this method is often integrated with Tahlily method since this method is often not discussed individually. By this method, a mufassir merely explains the contents of the verse in general (Murtadha \& Mutawali, 2017).

\section{Findings and Discussion}

\section{Quraish Shihab's Thought in Tafseer Almisbach}

The tafseer in the Discourse 'Ulum al-Qur'an' according to Quraish Shihab serves as a key to open the realm of the Qur'an, meaning a locked door and is difficult to open without a key. Therefore, how important and how high is the position of the tafseer. At least there are three reasons he presents that makes and determines the height (significance) of tafseer, namely (1) that the field of his study is the divine word which is the source of all religious sciences and virtues, (2) the objective is to encourages humans to cling firmly to the Qur'an in the effort to attain real happiness, (3) when it is viewed from the needs, it seems perfectness of various problems in life is the sharia sciences and knowledge of ins and outs of religion. It is greatly dependent upon the sciences of the Qur'an.

Realizing the broad meaning contained in the Qur'an, either the one dealing with the implied meaning behind the explicit meanings, Shihab by citing an opinion proposed by Arqoum, a contemporary thinier al-Jazair "Al-Qur'an " gives unlimited possible meanings. The impression he gives about his thought and explanation is in absolute form. As a result, the verses of the Qur'an are always open to being given new interpretations, are never certain and closed in a single interpretation". That is why the new and contextual reinterpretation in line with the development of the era and the community is a necessity the Qur'an does not intend to be left by the Umah of Islam or be buried in the fast-moving historical process.

In line with the opinion given by Arqoum above, Shihab has put forward the four principles where the ulema or Islamic thinkers (mufassirs) to find the verses of the Qur'an cannot be freed from the four principles:

1) The Qur'an al-Karim that was firstly known by the human society in 15 centuries ago is one of the Holy Books revealed by God as the guide for humans that give answers to the problems they encounter, although there are some differences among many verses describing situations and conditions of certain communities they do not deter their main functions as stated above.

2) The Qur'an either implicitly or explicitly recognizes the reality of social changes, the changes that should absolutely occur, quickly or slowly, whether they are realized or not. Even the Qur'an describes how the changes may happen, besides beckoning that a change naturally follows a pattern that has become sunnatullah so that it generally prevails.

3) The Qur'an al-Karim in a number of its verses condemns the people who do not attend the contents of the Qur'an and also criticizes those who just follow the old traditions without logical reasons, besides advocating the followers to think, observed while 
taking lessons from the experiences of the previous generations.

4) The differences in the results of human thoughts are a reality that cannot be avoided. They are not merely caused by differences in one's intelligence or educational background, but they are also affected either consciously or unconsciously by historical events, politics, and also others' thoughts that develop and the community condition.

In line with the thought above, there are three significant problems caused by social changes that should be attended by the muffassirs namely language, science, and method. It has been an agreement among mufassirs that Arabic is an important factor to be able to understand the content of the Qur'an, but it is also vital to notice the development of the language itself. It should be realized that if we hear a word, what emerges in a mind is the material description of the word. But on the other hand, the form of the material can develop in line with the change of the community. For instance, we can take an example the word $\quad$ iارlat the time of the revelation, its meaning was about ants/ant heads, the dust that flies and the like, but now it has an additional meaning that was not known before namely atom.

The second is science. The tafseer of the verses of the Qur'an that is not separated from a variety of patterns, methods and the exegesis results of the verses of the Qur'an may also not be avoided because of the advancement of the sciences. Therefore, it can be understood that the exegeses made by the previous ulema do not bind the interpretations at present or in the future.

The third is the method. Each mufassir has his own method in interpreting the verses of the Qur'an. The exegesis can be different between one muffasir and the other. So far as said by al-Farmawi, there are four types of exegesis method developed: Tahlili, ljmali, Muqarin, and Maudlh'i. Each method has its own weaknesses and strengths.

\section{a. Tafsir Al-Mishbah}

The most monumental work by M. Quraish Shihab is Tafsir al- Mishbah. The book consisting of 15 volumes started being written on Friday, Rabi'ul Awal 4, 1420/June 18, 1999 M in Cairo and finished on Friday, Rajab 8 1423/September 5, 2003 M. in Jakarta. Tafsir al-Mishbah is a tafseer of The Qur'an for 30 juzz altogether. The writer provides unique and interesting colors which are greatly relevant to enrich treasures of understanding and appreciation of the umah of Islam to the secret of the meanings of God's verses. The tafseer in Indonesian is the interpretation that is much studied by Islamic intellectuals of this nation. Some matters dealing with Tafsir al-Misbah are among others:

The motivation in writing Tafsir al-Mishbah is the concern M. Quraish Shihab felt with the growth of interest among the umah of Islam in Indonesia in The Qur'an, but most of them just stop in the reading of The Qur'an, as if this book is revealed to read-only. Even though it is not only read but also accompanied with the awareness to do tadzakkur and tadabbur. Moreover, there is a lot of umah of Islam in Indonesia who own an extraordinary interest in the meanings of The Qur'an. But they are hindered by their limited time to provide themselves with the supporting knowledge to be able to understand The Qur'an directly and the scarcity of reference books that are adequate in terms of the information 


\section{Sa'dullah Assa'idi et.al.}

content, the clarity, and the concise language about The Qur'an.

The reality triggers a motivation for $M$. Quraish Shihab to write a tafseer of the Qur'an to help correct the mistake and to give a correct impression about the messages of The Qur'an. Then Tafsir al-Mishbach was written of which one of its strengths lies in its ability to explain the main themes of the surahs of The Qur'an, and the main goals of the messages stated in its verses with the hope that this book may become a light for those who are looking for instructions and guidelines for life.

The decision made by the author in choosing the word al-Mishbah to name his tafseer book may be traced from the introduction of the work. In the introduction, the meaning of al-Mishbah is found where it means lamp, light, lantern, or another stuf with a similar function, which essentially is to enlighten those in the dark. From the choice of the word in the exegesis, it is fathomed that Muhammad Quraish Shihab expects to explain to anyone who is searching for directions and guidance for life, especially those who have difficulty in understanding the Qur'an directly due to the language barrier.

\section{i). The Tafseer Method Adopted in Tafsir Al-Misbah}

At least there are three tafseer methods used by M. Quraish Shihab. These three tafseer methods have developed among the writers of the interpretation of the Qur'an, namely tahili, muqaram and maudhu'i methods. The first method is conducted by making an exegesis on the basis of the order of the verses in the Qur'an. The second method, which is a comparative method is conducted by describing various views from others either classical or contemporary views. Then semi maudhu'i method is made by explaining the main themes of the surahs of the Qur'an, or the main goal around the verses from the surahs is to help correct the mistakes and create correct impressions. Concerning the reason why he combines the three exegesis methods simultaneously, it is explained in the introduction of his book.

\section{ii). The Tafseer Sources of Tafsir Al-Misbah}

The tafseer sources used in Tafsir Al-mlshbah are two. The first is from the writer's ijtihad. Second is that to strengthen his ijtihad he uses reference sources from the ulema's fatwas and opinions either the previous or contemporary ulema. Besides citing the ulema' opinions, he also uses the verses of the Qur'an and the Prophet's hadiths as part of the tafseer he makes. Therefore, Tafsir Al-Mishbah may be categorized as (exegesis) tafsir bi al-Ra'yi.

\section{iii). The Pattern of Tafsir Al-Mishbah}

In line with the intentions in writing this book as the illuminator for those searching for directions and guidance for life, this exegesis has a pattern of adabi ijtima'i, namely an interpretation that tends to interpret matters around social affairs or an exegesis that is present to always give answers to anything becoming the problems encountered by the umah, so that it can be stated that the Qur'an is appropriate to be used as the directions and guidance. The Qur'an in M.Quraish Shihab's view has three aspects: 1) aqidah, 2) 
syariah and 3) morals.. In the effort to attain the three aspects, The Qur'an possesses 4 ways, namely:

a) An instruction to give attention/make tadabbur to the universe;

b) An instruction to examine the growth and development of human beings;

c) Stories (a lesson, uswah, ibrah and also gentke warning);

d) The promise an also threat either worldly or ukhrawi.

\section{iv). The Writing System of Tafsir Al-Misbah}

Before interpreting a surah, M. Quraish Shihab first gives the preface. The content among others is the name of a surah or its other name, the number of verses (sometimes it is accompanied with the explanation of the differences in calculation and the like), the place of the revelation of the surahs (makiyyah and madaniyyah) and also exceptions of the verses that are included into the category, the reasons in choosing the surah, and the number of surahs based on the order of the mushaff, the main theme, the linkages or munasabah among surahs before and after the revelation of verses.

After presenting the preface, M. Quraish Shihab starts interpreting by making an analysis chronologically and describing various aspects contained in the verses of The Qur'an according to the order of the mushaffs reading It is intended to prove that the verses and the surahs of the Qur'an owns a perfect harmony and is an inseparable unity. M. Quraish Shihab is one of the mufassirs who always gives great attention to the verse munasabatul. this can be seen from all of his tafseer that always try to related word for word, the relation between the content of a verse and the fashilat namely the closing verses, the connection between a verse and the next verse, the initial description, and the closure, the closure of a surah and the description of the beginning of the next surah and also the relationship between the theme of a surah and its name. The systematics use in writing his exegesis is as follows:

1) It starts with an explanation of a surah in general: The grouping of verses in line with certain themes adjusted with a big theme related to the verses, then followed by the description of the verse, the translation, and the exegesis of the verse.

2) Doing munasabah between a verse/a theme of the previous verses and the verses interpreted.

3) Describing vocabulary is considered important to interpret the meaning of a verse.

4) Inserting a modifying word as the explanation of a meaning or the insertion is a part of the word or sentence used in the Qur'an.

5) The verses of the Qur'an and the Prophet's sunnah that serve as the supporter or the part of the tafseer are written in their translations only.

6) Explaining verses and the As-Syu'ara' ayat 181-183, M. Quraish Shihab also presents tafseers made by other mufassirs, most are expressed with the aim of strengthening or compromising the exegeses.

7) Closing the tafseer of a versed with the description of the munasabah of the verses interpreted and the previous verses. 
Sa'dullah Assa'idi et.al.

\section{Integrated Quality Education Management in Tafsser Al Misbach}

The surah As-Syuara' verses 181-183 in Tafsir Al-Misbah, according to M. Quraish Shihab, explained: "Give full measure and don't become ones cause who lose, and weight with scales true and upright and don't harm humans in terms of their rights, and don't be rampant on earth by making destructions; After the Prophet of Allah, Syu'ayb advised his people, they as if asked: What should we do?" He answered: "Give full measure and what is measured if you measure to others, as you measure for yourself, and don't be included into one of the group members widely known as those harmful to themselves because they harm t others, and moreover, weight for yourselves and for others with proper and upright scales. And don't harm humans over their stuff, namely their rights, by reducing the content or value and don't make crimes on earth by becoming destroyers in any form after it is repaired by Allah and also humans. Give full measure and don't become one of the group members who harm himself because of harming others. "And weigh for yourself and others with the true and straight balance.

Surah As-Syu'ara' consists of 226 verses. All of them according to the majority of ulema were revealed before the Prophet moved to Medina. There are also some ulema who exclude some verses, like the verses 224 to 227 talking about the poets because they guessed that the criticism to the poets and the exclusion of verse 197 about Israelites ulema with the reason that the association between the umah of Islam and the new Israelite prominent figures occurred in Medina. However, the exclusions were weak.

The popularity of this surah is very great since it threatened the poets, since they were considered by the Arabic society when the Quran was revealed at that time to be a respected medium. At that time they can be likened to the mass media now, which may spread information to elevate someone or a certain community or discredit him/them.

These verses talk about the Prophet of Allah, Syu'ayb as who was sent by Allah to Madyan, located in the red sea beach, the southeast of the Sinai desert, specifically between Tabuk in Saudi Arabia and the bay. Allah had sent him to them, then he advised them to give full scales and measures, and not to commit abuse on the earth, but they denied it.

Then Allah heated them up, they entered into holes, then their temperature went up. Allah umbrellad them with the clouds, then they gather under the clouds, but then Allah showers them with fire that makes all of them burned. At that time the Prophet of Allah, Syu'ayb ordered them to perfect the weigh and scaling practices completely and forbade them to fudge in the matter, that the believers are instructed to scale and to weight correctly.

Etymologically, munasabah means compatibility, relationship, or relevance, namely the compatibility relationship between one verse or surah and the previous and the next one. Terminologically, munasabah is a science to know the reasons to control the parts of the Holy Qur'an. Moreover, it is also stated that munasabah is the relationship of one sentence and the other sentence in a surah, between one verse and the other in various verses, or the relationship between one surah and the others.

Munasabah, the mufassirs remind us that in understanding or interpreting the verses 
of the Qur'an, especially those dealing with scientific exegesis, one is required to take into account the linguistic aspects of the Qur'an and also the correlation among the verses. It is known that the order of the verses of the Qur'an is not always based on the chronology of its revelation, but on the correlation of the meanings of the verses, so that the contents of the previous verses are always related to those of the next verses.

Munasabah has great roles in the exegesis, namely among others: (a) Finding out implied meanings and the order of the sentences or verses and surahs of the Qur'an so that parts of the Qur'an are that interrelated and seem to become one complete and integral series; (b) Facilitating the understanding of the Our'an; (c) Strengthening the faith of the truth as God's revelation, and (d) Denying accusations that the order of the Our'an is messy,

\section{a. Munasabah Surah}

It is alphabetical letters at the beginning part of the surahs of the Qur'an like: Alif laam miim, Alif laam raa, Alif laam miim shaad, and the like. Among the experts in exegesis, they leave the meanings to Allah since it is considered to include the mutasyaabihaat verses, but some interpret them. For those who interpret them, some view them as the names of the surah, and some say that the alphabetical letters are useful to attract attention to the Listeners so that they notice the Qur'an and to hint that the Qur'an is revealed from Allah in Arabic consisting of alphabetical letters. They do not believe that the Qur'an is revealed by Allah and it is merely made by the Prophet Muhammad SAW and let them make one like The Qur'an.

This surah begins with God's word: Tha'sin. It means that the series of letters is like that, and the one that will come to the Prophet Muhammad SAW is the verses of the Qur'an which are verses of a very perfect book and that explain any type of matters of human life happiness. These verses are a guide and good news for the beliefs with strong faith. The verses of the Qur'an and the verses of a greatly perfect book that explain all problems of the happiness of human life or that's very clear in its source namely Allah SWT on the basis of the miracle and privilege contained in it. The verses are hints and good news for the believers with strong faith.

\section{b. Tafsir Ibn Kathir}

Give full measure, and do not become one of the group members who harm yourself and others due to make loss to others. "And weigh for yourself and others with the true and straight balance. Don't harm others concerning with their rights reducing the content or value of something, and also don't mischief in the land by becoming destroyers in any form after the improvement made by Allah or by humans.

\section{c. Tafsir Fi Zhilalil Qur'an}

It is about the story of the Prophet of Allah, Syu'ayb, and before it, the order of its history before the story of the Prophet of Allah, Mose AS. It emerged in a series of lessons as in other stories in this surah. The population of Aikah was surrounded by dense and 


\section{Sa'dullah Assa'idi et.al.}

shady trees. It seemed that the Madyan country was filled and surrounded by dense trees. The location of the Madysan country is between Hijaz Palestine around Aqobah bay.

Perfect your measure and don't be one of the harmful people, and weigh with a straight scale and don't harm others in terms of their rights and don't tyrannize on earth by making damage. Syu'ayb through his warning to his people as other Prophets did before started by discussing the basic faith and attitude not to ask any reward for specific thins they encountered. Their behavior as stated surah al-A'raf and surah Huudd was to reduce scale and measure. They often took more by fulfilling and over-weighing for them. When they weighed for others, they weighed less. They bought at low prices, but sell at high prices.

It seemed that their country was often passed through by trade caravans so that they could control them. Their Prophets also asked them to behave in a just and balanced manner in the trading, correct faith is followed by correct behavior. And, the faith could not close eyes from the truth and justice in human interactions. Syu'ayb evoked the feelings of ta'wa in the spirits of his people, and he always reminded them about their Great Creator, the Creator of all generations, all the people.

\section{d. Tafsir Al- Maraghi}

$$
\begin{aligned}
& \text { ءلكم عليه من - • افتقو الله و اطيعون وماس2كذب اصحب لايكة المرسلين اذقال لهم شعيب الاتثقون اني لكم رسول امين } \\
& \text { اجران اجري الاعلي رب العلين رسين }
\end{aligned}
$$

After giving advice to them, then Syu'ayb gave other advice. Don't deny the rights of others in scales and measures or others, such as measurement and calculation. Where the forms of reducing rights were such as taking smaller eggs, buying small bread and taking big bread and so on, then prohibiting them to do great crimes by for example make any forms of destruction on earth.

\section{Implication of Integrated Quality Education Management Based on Tafsir Al-Misbah Surah}

Focusing on consumer/customer is the principle to accentuate satisfaction and to meet customer expectation. Efforts to realize the customer satisfaction should be made since customers naturally should be respected. See the hadiths:

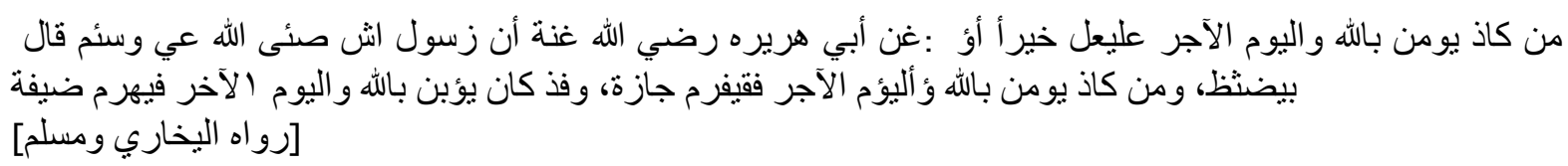

From Abu Hurairah radhiyallahu anhu, actually Rasulullah Shallallahu 'alaihi wa Sallam has stated: "Anybody who believes in Allah and the Last Day should not harm his neighbor, and anybody who believes in Allah and the Last Day should entertain his guests generously and anybody who believes in Allah and the Last Day should talk what is good or keep quiet. (i.e. abstain from all kinds of evil and dirty talk)" (Bukhari no. 6018, Muslim no. 
47).

One of morality that cannot be separated from social life is the ethics in honoring guests. "Honor" may be defined as considering or (viewing) noble, (very) respecting, holding high others. Therefore it can be said to praise and to satisfy customers is to give good welcome, to respect and to hold high others (customers) attending by showing readiness and happiness for their presence, and make the process of giving the best services to them. Honoring guests is an obligation for all Muslims, and being a guest is Islamic religious teaching, the habits of the Prophets, and other shalih persons. A Muslim believes in Allah and they must believe in the obligation to respect guests in accordance with his/her standing.

This shows that the deeds are a matter of creed. It has been explained that deeds are included in faith. Allah SWT announced through the mouth of His noble prophet that the matter of respecting guests deals with the perfection of one's faith to Allah SWT and the doomsday of which the two are part of the five pillars of faith and should be believed by each individual Muslim. As a result, the mark of perfection of one's faith may be known from one's attitudes towards his guest. The better he welcomes and entertains guests, the higher the value of his faith to Allah SWT will be. Otherwise, when he has less attention (look down) to his guest, this shows that his faith in Allah SWT is less perfect. The acts of faith themselves are sometimes related to Allah's rights, like doing obligations and leaving anything forbidden. What is included in the acts of faith is to say something good or to be silent. The acts of faith sometimes deal with the rights of the servants of Allah, for example, honoring guests, glorifying neighbors, and the act of not hurting them. The three matters are instructed to a believer, where one of the instructions is to say something good or to keep silent from any bad words, namely trying to respect his customers in speaking every day.

Since honoring guests is one of the requirements of one's faith, a manager of an educational institution should be responsive to customers' all desires and expectations. Especially at present, where competition among education institutions is strict. As a result, an educational institution greatly affects customers' interest, so that it needs ab accurate strategy to do that. Essentially, a customer satisfaction strategy will cause the competitors to work hard and it needs high costs in the effort to seize the customers of a service provider (an educational institution).

Based on the surah As-Syu'ara' verses 181-183 in Tafsir Al-Misbah, M. Quraish Shihab explains that "Give full measure and don't become ones cause who lose, and weight with scales true and upright and don't harm humans in terms of their rights, and don't be rampant on earth by making destructions. This verse explains that the believers are commanded to replenish measure and weigh correctly. Others' rights should not be taken and making any destructions on earth is forbidden. It means that customers will be satisfied if the corporation/the educational institution does not do anything that harms its customers. One of them is by improving the services or products until they may equal or exceed the customers' needs and expectations. Therefore, they may feel two types of satisfaction namely the satisfaction during the process of buying and the satisfaction with 


\section{Sa'dullah Assa'idi et.al.}

using the product (quality). In the concept of Islam, producing something beneficial for oneself and others is the application of the values of faith so that it has a worship value by Allah's side and it is given His mercy and blessings.

Therefore, Islamic education should understand that each product of education possesses users (customers). Each member of Islamic education is the supplier and the user (customer). There are two customers here, namely internal and external ones. Internal customers include student parents, students, teachers, administrators, staff, and school assembly.

External customers are the community, heads of corporation-industry, government institutions, a private institutions, high education, and security agency. Islamic education will be regarded to have high quality and will attract the community if it is able to fulfill the customer expectations and satisfaction either internal or external ones. Therefore, Islamic education is required to possess good services, transparent management, good communication among school citizens and to be able to mold students in accordance with the concept of Islamic education namely superior students in terms of knowledge, skills, and morality (akhlakul karimah).

Give full measure, and do not become one of the group members who harm yourself and others due to make loss to others. Besides, weigh for yourself and for others with an accurate scale. Don't harm others dealing with their rights by reducing the content of the value of something and don't do crimes on earth by becoming the destroyers in any form after its improvement is done by Allah or also by humans. Namely, if you give something to humans, perfect its weight and don't reduce its heaviness so that you give it in its less weight. But, take it as you give it and give it as you take it.

So if it is related to the context of education, the concept of the quality of education is elite, since there are few institutions that may give educational experiences with high quality to the students. In the relative sense, quality has two definitions. The first is to adjust oneself to specifications. The second is to meet customers' needs. Quality in someone's eyes is sometimes in contradiction with the one in others' eyes so that it is natural if there are experts who do not have the same conclusion of how to create a good institution. The improvement of the quality of education is one of the main pillars in building education in Indonesia since if the education is of good quality, it will produce intelligent and competitive human resources.

Therefore, in the context of the management of improving the quality of Islamic education, something is said to be excellent if it gives goodness either for himself (the educational institution itself), for others (stakeholders and customers). What is meant by giving goodness is that it is able to satisfy the customers. Dealing with integrated quality management, Edward Sallis stated that integrated quality management is a philosophy of continuous improvement, that may give a set of practical tools to each educational institutional in fulfilling needs, desires, and expectations for its customers at present or in the future. 


\section{Conclusion}

In summary, tafseer Almisbach by Quraish Shihab provides enlightens how quality management and customer satisfaction are served in the Islamic education system. Os verses have indicated deeds Muslims should interpret the indicators of quality management in education. This study indicates a novelty that the richness of education quality management rooted from Alquran and hadits show that epistemologically, it is a continued improvement that Allah has indicated as well as the world and life go through. This study, however, indicates a restriction in that the tafseer on the education management theories is content-based analysis. To improve the weaknesses, future research is suggested to have multiple research methods, applying the content analysis and confirming the results with Islamic experts and practitioners who operate educational institutions in practices.

\section{BIBLIOGRAPHY}

Briggs, K. L., \& Wohlstetter, P. (2003). Key elements of a successful school-based management strategy. School Effectiveness and School Improvement, 14(3), 351-372. https://doi.org/10.1076/sesi.14·3·351.15840

Bunza, Umar, Mukhtar \& Abdulkarim, Lawal. (2021). Scientific Education among Muslims in Northern Nigeria: The Influence of Middle Eastern and Midetaraion Scholarship. Dinamika Ilmu, 21(1): 1-6. DOI: 10.21093/i/v21i1.2554.

Crawford, L. E. d., \& Shutler, P. (1999). Total Quality Management in Education: Problems and Issues for the Classroom Teacher. International Journal of Educational Management, 13(2), 67-73. https://doi.org/10.1108/09513549910261122

Hermanto, M. (2018). Manajemen Mutu Terpadu dalam Pendidikan Islam. Al- Muaddib Jurnal Ilmu-Ilmu Sosial \& Keislaman, 3(1), 1-26.

Hidayat, R., \& Wijaya, C. (2017). Ayat-ayat Al-Qur'an tentang Manajemen Pendidikan Islam. In A. Zein (Ed.), Lembaga Peduli Pengembangan Pendidikan Indonesia (1st ed., Vol. 1). Lembaga Peduli Pengembangan Pendidikan Indonesia (LPPPI).

Komariah, Aan \& Cepi Triatna. (2008). Visionary Leadership: Menuju Sekolah Efektif. Bumi Aksara

Mann, T. (2005). The Oxford Guide to Library Research (T. Mann (ed.); Third). Oxford University Press.

Mellon, C. A. (2015). Library Anxiety: A grounded theory and its development. College and Research Libraries, 76(3), 276-282. https://doi.org/10.586o/crl.76.3.276

Murtadha, R., \& Mutawali, M. (2017). Tafsir ljmali Sebagai Metode Tafsir Rasulullah. Project: Pendidikan Dan Pemikiran Islam, 1-13. https://doi.org/10.31227/osf.io/7dhbr

Rukiyah, Ity; Kadir, Marniati \& Ulfah, Zakiyah. (2021). Challenges of Managerial Functions Emerging within IGRA Professional Organizations in East Kalimantan. Dinamika Ilmu, 21(1), 71-88. DOI: 10.21093/di.v21i1.3061.

Salih, B. T. (2008). Total Quality Management in Education. Zanco Journal, 36, 83. 
Sa'dullah Assa'idi et.al.

https://doi.org/10.4324/978020342366o_chapter_5

Sallis, E. (2014). Total quality management in education: Third edition. In Total Quality Management in Education: Third Edition. https://doi.org/10.4324/9780203417010

Saputro, A. (2015). Implementasi Manajemen Mutu Terpadu Di Sekolah/Madrasah. Jurnal Al-Idarah, 5(2), 121-137.

Stemler, S. E. (2015). Content Analysis. In R. Scott \& S. Kosslyn (Eds.), John Wiley \& Sons, Inc. John Wiley \& Sons, Inc.

Taufikin. (2021). Pesantren as the Three Centers of Education Perspective of Ki Hadjar Dewantara. Dinamika llmu. 21(1), 101-136. DOI: 10.21093/di.v21i1.3149.

Vlašić, S., Vale, S., \& Puhar, D. K. (1996). Quality Management in Education. Quality Management in Education, 1, 565-573. https://doi.org/10.4324/9780203277843

Yasin, H. (2020). Mengenal Metode Penafsiran Al Quran. Tahdzib Al-Akhlaq: Jurnal Pendidikan Islam, 3(1), 34-51. https://doi.org/10.34005/tahdzib.v3i1.826 